\title{
Taloussosiologian oppikirja markkinoiden ja rahan maailmaan
}

Paul Jonker-Hoffrén, VTT, postdoc-tutkija, historian, kulttuurin ja taiteiden tutkimuksen laitos, Turun yliopisto

Jukka Gronow: Deciphering Markets and Money - A sociological analysis of economic institutions. Helsinki University Press: Helsinki, 193 sivua. 2020.

Sosiologian professori emeritus Jukka Gronow on julkaissut taloussosiologian perusteoksen, joka voidaan nähdä Richard Swedbergin (2009) teoksen Principles of Economic Sociology jatko-osana. Osittain teos käsittelee samoja teemoja, mutta ottaa selkeästi uudempaa tutkimusta mukaan. Teoksessa on myös erilainen ote talouteen. Sitä voidaan pitää dialogina taloustieteen kanssa siitä, miten yhteismitallisuuden ongelma (commensuration) voidaan ratkaista. Kirja on tervetullut ja perusteellinen lisäys taloussosiologian kirjallisuuteen, erityisesti siksi, että Gronow käsittelee ansiokkaasti rahan, arvon ja rahan arvon ilmiöitä. Teoksella on annettavaa niin opiskelijoille kuin varttuneille taloussosiologian asiantuntijoille. Tämän ydinyleisön ohella kirja on tärkeää lukemista myös taloustieteen tutkijoille ja päätöksentekijöille.

Deciphering Markets and Money pyörii Gronowin mukaan kahden kysymyksen ympärillä: mikä on sosiologian suhde taloustieteisiin ja mikä sosiologian kontribuutio voisi olla talouden instituutioiden analyysiin. Kirjan ensimmäinen luku kuitenkin alkaa perustavanlaatuisemmasta kysymyksestä: miten vertailla sitä, mikä on lähtökohtaisesti vertailukelvotonta? Luku esittää yleisesti taloussosiologian tärkeimmät tutkimuskysymykset eri kirjoittajien kautta, rajautuen erityisesti kapitalistisen talouden tutkimukseen. Tämä tutkimuskohde vaatii omat käsitteet, analyyttiset työkalut ja kehykset, jotta tutkimuksessa päästäisiin kapitalistisen markkinatalouden sosiaalisiin ja historiallisiin perusteisiin käsiksi (s. 5). Tämän yhteydessä nousee esiin kirjan tärkein lähtökohta: miten markkinoilla kaupattavat tavarat tehdään verrattaviksi ja 
yhteismitallisiksi? Tässä tärkeässä roolissa ovat raha ja pääoman kirjanpito (capital accounting). Ensimmäisen luvun lopussa Gronow käsittelee kriittisesti taloustieteen utiliteetin käsitteen (utility), sosiologian pyrkimykset selittää tavaroiden raha-arvon eroja ja erilaisten asioiden vertailun yleisiä lähtökohtia. Tässä keskeinen käsite on yhteismitallistaminen (commensuration), jolla Gronowin mukaan ominaisuudet (qualities) muutetaan määriksi (quantities), joita voidaan helpommin vertailla.

Kirjan toinen luku on historiallis-teoreettinen katsaus taloussosiologian kehitykseen. Osa lukua perustuu selkeästi "klassikkoihin" (Weber, Durkheim, Simmel, Veblen ja Marx). Gronowin ote on näiden osalta esimerkiksi Swedbergia (2009) analyyttisempi, minkä lisäksi hän tukeutuu myös uudempaan tutkimuskirjallisuuteen. Toisaalta lukua voidaan pitää myös erittäin perusteellisena katsauksena Max Weberin teokseen Talous ja yhteiskunta (Wirtschaft und Gesellschaft). Tämä on luonteva valinta, koska Weber käsittelee klassikoista perusteellisimmin yhteismitallisuuden ongelman. Gronow käyttää uusinta Weber-tutkimusta kartoittamaan Weberin ajatuksia suhteessa taloustieteen kenttään. Vaikka Weberillä on selkeästi oma kontribuutionsa taloustieteille, Gronow näkee, että hänen ajatuksensa ovat kenties yllättävänkin lähellä taloustieteen niin kutsutun itävaltalaisen koulukunnan keskeisiä edustajia (mm. Schumpeter).

Kolmas luku kysyy: mitä on raha? Luvussa asiaa käsitellään klassikoiden, kuten Smithin ja Marxin kautta, mutta varsinkin luvun alku keskittyy kritisoimaan niin kutsuttua rahan vaihtoteoriaa (exchange theory of money). Gronow ihmettelee, miksi useat, laajalti käytetyt taloustieteen oppikirjat edelleen viittaavat kyseiseen teoriaan, vaikka tämä on empiirisen evidenssin valossa heikko ja luonteeltaan lähestulkoon myyttinen. Hän esittää myös useita muita vähemmän tunnettuja rahan teorioita, kuten Knappin valtion rahateorian (s.54). Luku jatkuu Keynesin ja chartalismin teoriaperinteen käsittelyn kautta keskustelemaan Simmelin ja Marxin ideoista rahasta. Myöhemmin Gronow yhdistää uusinta tietoa tuttuihin aiheisiin ja lähestymistapoihin. Tämän valossa luvun alku vaikuttaa kummalliselta, koska se käsittelee varsin vanhoja taloustieteen rahateorioita. Käsittely seuraa kuitenkin loogisesti edeltävää lukua, koska raha on yksikkö, jonka kautta asioiden arvoa vertaillaan. Luku onnistuu käsittelytapansa vuoksi osoittamaan, että raha on lähtökohtaisesti hankala arvon mittari. 
Näiden koko teoksen perusteita rakentavien lukujen jälkeen Gronow siirtyy käsittelemään sosiologisia markkinateorioita. Lukua 4 voidaan pitää yhtenä kirjan varsinaisista pihveistä. Markkinat ovat yksi taloussosiologian ydinaiheita muun muassa siksi, että taloustieteen teorioiden sisällä ei yleensä ole selitystä sille, mistä markkinat tulevat. Vaikka Gronow käsittelee taloussosiologian klassikoita, kuten Parsons, Granovetter ja Fligstein, tässä luvussa eniten tilaa annetaan uudemmalle taloussosiologialle. Hän käsittelee erityisen ansiokkaasti Patrik Aspersin markkinoiden teoriaa, jossa tehdään jaottelu markkinoihin, joilla on vakioroolit (myyjä tai ostaja) tai vaihtelevat roolit (myyjä ja ostaja), sekä status- ja standardimarkkinoihin. Standardimarkkinat ovat markkinat, joilla on lukuisia myyjiä ja jotka myyvät standardituotteita. Tämä tarkoittaa, että yhden myyjän tuote voi helposti korvata toisen myyjän tuotteella. Tässä tapauksessa myyjän sosiaalinen identiteetti on yhdentekevää, toisin kun statusmarkkinoilla. Esimerkkinä ensimmäisestä on omenamarkkinat, toisesta autojen markkinat, joilla BMW:lla on erilainen sosiaalinen arvo kuin Hyundailla. Harrison Whiten markkinateoriaa sen sijaan käsitellään teoksessa turhan suppeasti otetaan huomioon kyseisen teorian monimutkaisuus (s. 75-78). On kuitenkin merkittävää, että White saa paikan taloussosiologian oppikirjassa. Markkinateorioiden ohella Gronow käsittelee erilaisia (talous)sosiologian pyrkimyksiä ymmärtää arvon syntyä. Taidehuutokauppojen, käytettyjen autojen markkinoiden ja tieteellisten julkaisujen esimerkkien kautta hän tuo esiin taloussosiologian keskeiset markkinakäsitteet, kuten laadun epävarmuus (quality uncertainty) ja markkinakojeet (market devices). Näiden avulla hän kertoo tutkimuksista, joiden avulla on havaittu, kuinka vaikeaa on arvioida viinin tai tieteellisten tekstien arvoa. Viinioppaiden ja sitaatti-indeksien kaltaiset markkinakojeet ovat keinoja jonkinlaisen arvion tekemiseen. Luvun lopussa Gronow pohtii, miten tällaiset empiiriset ja teoreettiset löydökset voidaan suhteuttaa taloustieteen hinnanmuodostusteorioihin.

Teoksen viides luku siirtää keskustelun neljännen luvun tuotemarkkinoista laajempaan yhteiskuntaan. Gronow käsittelee teoksen viidennessä luvussa "maun kolmea sosiaalista rakennetta" (s. 105) eli muotia, sosiaalisia maailmoja ja kulttuurin kenttiä. Tämä kolmijako on tuttu sosiologian klassikoista ja perustuu Simmelin, Howard Beckerin ja Bourdieun näkemyksiin. Nämä kolme sosiaalista rakennetta ovat mekanismeja, joiden kautta objekti voi saada arvoa. Luvun tarkempi analyysi kohdistuu asiantuntijoiden rooleihin 
mielipiteiden muodostamisessa, eliitin tapoihin erottaa kulttuurisia mieltymyksiä muista ja arvonmuodostukseen sen kautta, mikä on milläkin hetkellä muodikasta. Kuudes luku on tavallaan jatkoa tähän lukuun. Luku käsittelee sitä, miten lähes kaikesta on tullut esteettisiä kokemuksia ja miten tämä vaikeuttaa arvonmuodostuksen ja varsinkin yhteismitallisuuden tutkimusta.

Seitsemäs luku palaa osittain rahan teemaan, kun Gronow käsittelee rahoitusmarkkinoita. Jos edellisen luvun teemana oli "vain" arkisen kulutuksen estetisointi, on tämän luvun teemana "lähes kaiken" rahoituksellistaminen tai finansointi (financialization). Luvussa käsitellään sekä uusia että vanhoja finansoinnin teorioita. Vaikka rahoitusmarkkinat pystyvät luomaan rahallista arvoa, Gronowin keskeinen huomio on, että tämä tapahtuu finanssimarkkinoiden omien markkinakojeiden kautta. Tällä hän viittaa esimerkiksi luottoluokittajiin ja riskianalyytikoihin. Tässä luvussa hän myös esittelee, millä tavoin rahoitusmarkkinat voivat olla performatiivisia. Hieman yksinkertaistaen tämä tarkoittaa sitä, että finanssimarkkinat toimivat vasta, kun niiden rakenteet on luotu. Performatiivisuuden osalta olisin mielelläni nähnyt Gronowin analyysia Michel Callonin töistä. Myös Callon kirjoittaa markkinakojeista osana performatiivisutta, mutta käsittelee samalla myös taloustieteen performatiivisuutta eli sitä, miten taloustieteen malleja ja oppeja käytetään muovaamaan yhteiskunnan rakenteita oppien mukaiseksi. Teeman käsittely olisi saanut lukuun kirjan kokonaistavoitetta ajatellen lisää terävyyttä.

Johtopäätösluvulla Gronow tiivistää kirjan pääteemat ja samalla vahvistaa, että sosiologialla on paljon annettavaa taloustieteen alalle. Noin sata vuotta taloutta tutkinut sosiologia on näyttänyt, että taloustiede yksin ei ole riittävä kuvaus taloudesta, vaan että sosiologian tutkimusaiheet täydentävät taloustieteen sokeita pisteitä. Tämä koskee nimenomaan taloustieteen markkinateorioita, joilla standardimarkkinoiden malli näyttää olevan enemmän sääntö kuin poikkeus. Gronow kehottaakin ottamaan vakavasti markkinoiden historialliset ja sosiaaliset kontekstit. Kirjan selkeä viesti on, että markkinat ovat aina erilaisia riippuen siitä, mitä siellä myydään ja miten. Gronow toteaa, ettei sosiologiallakaan ole tarjota lopullista ratkaisua arvon muodostumiseen taikka yhteismitallisuuden ongelmaan, mutta ainakin kirja osoittaa ne monet eri tavat, jolla ihmiset, yritykset ja instituutiot pyrkivät ratkaisemaan näitä ongelmia oman toimintansa osalta. 
Kirjassa on kuitenkin yksi heikko kohta, joka näyttää olevan ominainen taloussosiologian kentälle. Gronow ei juurikaan käsittele työmarkkinoita tai sitä, miten kirjan anti soveltuisi työmarkkinakeskusteluihin. On toki myönnettävä, että monet Gronowin käsittelemistä teoreetikoista, kuten Aspers (2011) peräänkuuluttavat, ettei ole vielä olemassa taloussosiologista työmarkkinateoriaa. Teoksesta käsitellyistä tutkijoista esimerkiksi Harrison White (1970) on tehnyt tärkeää työtä tällä saralla. Hän on muun muassa tarkastellut mekanismeja (nk. vacancy chains), joiden kautta avoimet työpaikat siirtyvät ketjumaisesti paikasta toiseen, kunnes on saavuttu "lopulliseen paikkaan", johon ihminen haetaan. Myös Granovetterin tutkimus vahvoista ja heikoista siteistä on tuttu teoreettinen käsite, jota käytetään kattavasti työn sosiologiassa. Nämä ja monet muut tutkimukset toteavat, että työmarkkinoiden toiminta perustuu pitkälti verkostoihin markkinamekanismin sijaan. Tämä voidaan nähdä myös alustatalouden tutkimuksessa. Vaikka joissakin alustoissa käytetään erilaisia huutokauppamekanismeja työn allokointiin, moni alusta muistuttaa kuitenkin enemmän digitaalista versiota heikoista siteistä (ks. esim. Jonker-Hoffrén 2020).

Tässä kontekstissa voidaan sanoa, että Gronowin kirjan vahvin anti on juuri se, miten yhteismitallisuuden ongelmaa käsitellään kirjassa. Se tarjoaa perusteen tarkastella kriittisesti taloussosiologiaa ja sen eri haaroja. Tämä ongelma on ehkä myös syy sille, miksi kirjassa ei käsitellä työmarkkinoita sen enempää. Tämä on nimenomaan se kenttä, jossa ongelma on suurimmillaan, eikä selittämisessä pystytä nojaamaan pelkästään markkinakojeisiin, vaan joudutaan tutkimaan myös yhteiskunnan normeja. Tässä mielessä Gronow vaikuttaa olevan lähellä kriittistä teoriaa kirjoittaessaan markkinoiden empiirisestä todellisuudesta.

Gronowin kirja on kattava näyte siitä, missä taloussosiologia on vuonna 2020. Teoksessa olisi voitu käsitellä performatiivisuutta vähän laajemmin esimerkiksi Michel Callonin (2007, ks. myös Callon ym. 2007) työn kautta, sillä myös Callon perehtyy syvemmin Gronowin mainitsemiin markkinakojeisiin. On myös jokseenkin yllättävää, että Gronow käsittelee kattavasti Jens Beckertin ja Patrik Aspersin teoksia, mutta ei näiden yhdessä toimittamaa teosta The Worth of Goods - Valuation and Pricing in the Economy (Beckert ja Aspers 2011), joka käsittelee pitkälti samoja teemoja. Teoksessa on myös luvut Fourcadelta ja Karpikilta, joiden muihin teoksiin Gronow viittaa runsaasti. 
Kirja ansaitsee erityisiä kehuja siitä, että teos on taloussosiologian oppikirjaksi harvinainen tapaus, koska se käsittelee myös Harrison Whiten vaikeaselkoista markkinateoriaa. Tämä kirja ansaitsee paikkansa jokaisella taloussosiologian peruskurssilla.

\section{Lähteet}

Aspers, Patrik. 2011. Markets. Cambridge: Polity.

Beckert, Jens, ja Aspers, Patrik (toim.). 2011. The worth of goods: Valuation and pricing in the economy. Oxford: Oxford University Press.

Callon, Michel. 2007. What does it mean to say that economics is performative? Teoksessa Donald McKenzie, Fabian Muniesa ja Lucia Siu (toim.). How economists make markets: The performativity of economics. Princeton, NJ: Princeton University Press, 311-57.

Callon, Michel, Millo, Yuval ja Muniesa, Fabian. 2007. Market devices. Oxford: Blackwell.

Jonker-Hoffrén, Paul. 2020. What is the employment potential of a lean platform? The case of Dutch self-employed service professionals. International Journal of Manpower. https://doi.org/10.1108/IJM-01-2019-0037

Swedberg, Richard. 2009. Principles of economic sociology. Princeton: Princeton University Press. 